\title{
GAMBARAN STATUS KARIES GIGI ANAK SEKOLAH DASAR KOTA MALANG
}

\author{
Rara Warih Gayatri \\ Mardianto \\ Fakultas Ilmu Keolahragaan Universitas Negeri Malang \\ e-mail: rarawg@yahoo.com
}

\begin{abstract}
This study aims to describe the caries status of primary school children in the city of Malang. The method used is descriptive method with cross-sectional design and was conducted in two elementary schools, SDN Kauman 2 and SDN Percobaan 2 Malang. The sampling method used is random sampling with the variable being measured is characteristic of primary school children by age, gender and DMF-T index. Techniques of data collection used are interviews and observations. The observation aims to conduct dental examinations using diagnostic tools 2 pieces of glass mouth. The data analysis is done by counting the total number of DMF-T each of the research subjects and the mean DMF-T of whole sample. Conclusion of the data results was analyzed using DMF-T index according to the WHO. The result of this study is DMF-T index of primary school children in the city of Malang is 5.75. The conclusion of this study is the prevalence of dental caries in elementary school in Malang city students is high. The need for policy improvements related to ease of access to obtain the services of dental and oral health care facilities for primary school children. Besides, the need for oral health program of comprehensive primary school with good coordination of related partnership. Further research on dental caries and risk factors is necessary.
\end{abstract}

Keywords: caries, DMF-T, elementary school children

\begin{abstract}
Abstrak: Penelitian ini bertujuan untuk mengetahui gambaran status karies anak sekolah dasar di Kota Malang. Metode yang digunakan adalah metode deskriptif dengan desain potong lintang (cross-sectional) dan dilakukan di 2 SD yaitu SDN Kauman 2 Malang dan SD Percobaan 2 Malang. Metode sampling yang digunakan merupakan metode random sampling dengan variable yang diukur adalah karakteristik anak sekolah dasar berdasarkan usia dan jenis kelamin serta indeks DMF-T. Teknik pengumpulan data menggunakan metode wawancara dan observasi dengan melakukan pemeriksaan gigi menggunakan alat bantu diagnostic 2 buah kaca mulut. Analisa data dilakukan dengan cara menghitung jumlah total DMF-T masing-masing subyek penelitian dan rerata DMF-T seluruh sampel. Kesimpulan hasil analisa data disesuaikan dengan pengukuran indeks DMF-T menurut WHO. Hasil dari penelitian ini adalah indeks DMF-T anak sekolah dasar di Kota Malang adalah 5,75. Kesimpulan dari penelitian ini adalah prevalensi karies gigi siswa sekolah dasar kota malang adalah tinggi. Perlu adanya perbaikan kebijakan terkait kemudahan akses memperoleh layanan fasilitas kesehatan gigi dan mulut bagi anak sekolah dasar. Selain itu perlu adanya program kesehatan gigi dan mulut yang komprehensif di sekolah dasar disertai koordinasi yang baik dari pihak terkait. Penelitian lanjutan mengenai karies gigi dan faktor resikonya sangat diperlukan untuk perbaikan penelitian ini.
\end{abstract}

Kata kunci: karies, DMF-T, anak sekolah dasar

Hampir $90 \%$ anak - anak usia sekolah di seluruh dunia menderita karies gigi (Bagramian dkk, 2009). Sementara itu, menurut Centers of Control disease Prevention (CDC, 2013), meskipun karies gigi merupakan penyakit yang harus bisa dicegah akan tetapi tetap menjadi penyakit kronis yang utama pada anak usia 6-11 tahun (25\%) serta remaja usia 12-19 tahun (59\%). Di Indonesia, prevalensi karies gigi juga cukup tinggi. Menurut hasil Riset Kesehatan Dasar 
(Riskesdas) Nasional tahun 2007, prevalensi karies di Indonesia mencapai $72,1 \%$ dan skor DMF-T mencapai 4,8 . Hal ini juga didukung oleh Survey Kesehatan Rumah Tangga (SKRT) tahun 2009 yang menunjukkan bahwa penduduk Indonesia yang menderita karies gigi sebesar 73\%. Sementara pada kelompok anak-anak, dalam SKRT tahun 2001 yang dilakukan Rahardjo (2007), terdapat $76,2 \%$ anak Indonesia pada kelompok usia 12 tahun (kira-kira 8 dari 10 anak) mengalami gigi berlubang. Temuan ini juga didukung oleh data

Kementrian Kesehatan Republik Indonesia (Kemenkes RI) tahun 2009 yang menunjukan sebanyak $89 \%$ anak Indonesia di bawah 12 tahun menderita karies gigi.

Definisi karies itu sendiri adalah penyakit jaringan gigi yang ditandai dengan kerusakan jaringan, dimulai dari permukaan gigi meluas kearah pulpa (Riyanti, 2005). Karies gigi dapat terjadi pada setiap orang yang dapat timbul pada suatu permukaan gigi dan dapat meluas kebagian yang lebih dalam dari gigi (Riyanti, 2005). Faktor utama penyebab karies yaitu host, mikroorganisme, substrat dan ditambah faktor waktu (Sondang dan Hamada, 2008). Selain itu, faktor resiko yang mempengaruhi keparahan karies antara lain pengalaman karies, sosial ekonomi, usia, jenis kelamin, pendidikan, geografis, dan perilaku terhadap kesehatan gigi (Sondang dan Hamada, 2008).

Pada umumnya, keadaan kebersihan mulut anak lebih buruk dikarenakan anak lebih banyak makan makanan dan minuman yang menyebabkan karies dibanding orang dewasa. Hal ini sesuai dengan pernyataan Machfoeds dan Zein (2005), anak-anak umumnya senang makan gula-gula, dan apabila anak terlalu sering makan gula-gula dan jarang membersihkannya, maka gigi-giginya banyak yang mengalami karies. Selain itu juga tingkat kesadaran untuk memelihara kesehatan gigi dan mulut oleh anak-anak sendiri juga masih tergolong rendah yang mana hal ini juga dipengaruhi oleh

rendahnya pengetahuan tentang kesehatan gigi dan mulut itu sendiri. Menurut survey yang dilakukan oleh Dewanti (2012) menunjukan bahwa terdapat hubungan yang signifikan antara rendahnya tingkat pengetahuan kesehatan gigi dan mulut anak-anak SDN Pondok Cina 4 Depok dengan buruknya perilaku memelihara kesehatan gigi dan mulut.

Merujuk dari gambaran kondisi tingginya prevalensi karies gigi pada anak usia sekolah dasar khususnya di Indonesia yang dipengaruhi oleh berbagai latar belakang faktor penyebab, maka perlu juga kiranya dilakukan survey prevalensi karies gigi pada anak sekolah dasar di Kota Malang. Data terkini mengenai prevalensi karies gigi anak sekolah dasar di Kota Malang dirasa perlu guna menunjang penelitian lebih lanjut mengenai kesehatan gigi dan mulut pada anak sekolah dasar. Saat ini, data prevalensi karies gigi yang terkumpul secara nasional dari berbagai provinsi, masih terdata tahun 2007 (Riskesdas, 2007). Adapun gambaran profil sekolah dasar di Kota Malang saat ini memiliki 325 sekolah dasar dengan rincian 193 sekolah dasar negeri dan 132 sekolah dasar swasta (Dinas Pendidikan Kota Malang, 2015). Menurut Badan Pusat Statistik (BPS) Kota Malang (2014), jumlah siswa sekolah dasar yang terdata dan tersebar di 5 kecamatan (

Kedungkandang, Sukun, Klojen, Blimbing dan Lowokwaru) sejumlah 76.542 murid baik negeri maupun swasta dan 10.322 murid sekolah dasar dibawah kementrian agama.

\section{METODE}

Desain rencana penelitian ini adalah penelitian deskriptif kuantitatif yang menggunakan rancang bangun cross sectional. Penelitian ini dilakukan di 2 dua sekolah dasar yaitu Sekolah Dasar Negeri Kauman 2 dan Sekolah Dasar Negeri Percobaan 2 kota Malang pada bulan Mei - Oktober 2015. Metode sampling yang digunakan adalah random sampling dari jumlah populasi seluruhnya sebanyak 718 anak sekolah dasar. Besar sampel dalam penelitian ini menggunakan rumus Krejeie \& Morgan 
diperoleh sebesar kurang lebih 251 anak sekolah dasar. Pengumpulan data diawali dengan memberikan informed consent kepada subyek penelitian yang selanjutnya pengisiannya diwakili oleh orang tua subyek peneliti.

Teknik pengumpulan data dengan melakukan pemeriksaan pada gigi menggunakan alat diagnostic kaca mulut dan sonde. Nilai Decayed (D) adalah gigi yang berlubang karena karies gigi, dimana ketika pada pemeriksaan ujung sonde tersangkut pada cavitas. Keadaan lain yang termasuk dalam kategori ini yaitu karies dengan kavitas besar yang melibatkan dentin Nilai Missing (M) adalah gigi yang dicabut karena karies gigi atau gigi permanen yang diindikasikan untuk pencabutan seperti mahkota gigi yang sudah hancur atau terdapat sisa akar. Sementara nilai Filled

(F) adalah gigi yang ditambal atau ditumpat karena karies dan dalam keadaan baik. Teknik analisis data dilakukan dengan menjumlahkan komponen nilai $\mathrm{D}, \mathrm{M}, \mathrm{F}$ kemudian rerata DMF-T adalah jumlah seluruh nilai DMF dibagi atas jumlah orang yang diperiksa. Klasifikasi hasil rerata DMF-T kemudian disesuaikan dengan makna indeks DMF$\mathrm{T}$ menurut WHO, 2003:

\begin{tabular}{cc}
\hline Kategori & DMF-T \\
\hline Sangat rendah & $0,8-1,12$. \\
Rendah & $1,2-2,6$ \\
Sedang & $2,7-4,4$ \\
Tinggi & $4,5-6,5$ \\
Sangat Tinggi & $>6,5$ \\
\hline
\end{tabular}

\section{HASIL}

Hasil penelitian mengenai gambaran status karies gigi anak sekolah dasar di Kota Malang, dilakukan pada 284 siswa yang terdiri dari 138 siswa SDN Kauman 2 Malang dan 146 siswa SDN Percobaan 2 Malang. Penelitian ini dilakukan pada bulan Agustus - Nopember 2015.

Objek penelitian berusia 6 sampai 12 tahun, terdiri dari 136 siswa perempuan dan 148 siswa laki-laki. Distribusi frekuensi objek penelitian dapat digambarkan pada tabel dan pie chart berikut:

Tabel 1 Distribusi frekuensi karakteristik responden:

\begin{tabular}{llcc}
\hline No. & Sekolah & Laki-Laki & Perempuan \\
\hline 1. & SDN Kauman 2 Malang & 73 & 67 \\
2. & SDN Percobaan 2 Malang & 72 & 72 \\
& Total & 145 & 139 \\
\hline
\end{tabular}

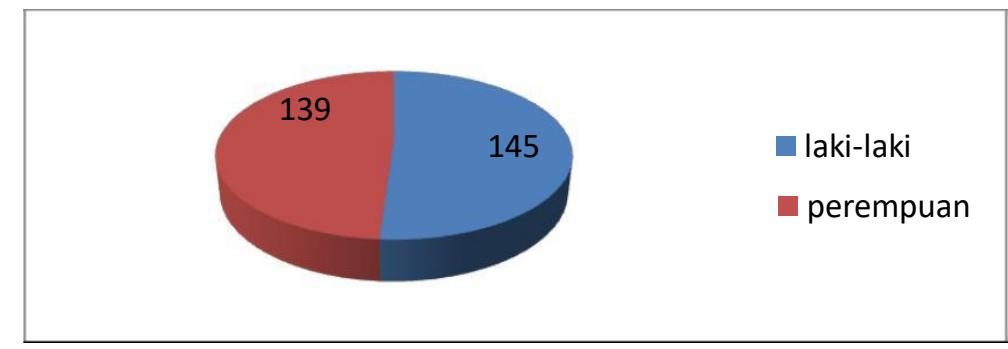

Gambar 1 Diagram distribusi frekuensi karakteristik responden berdasarkan jenis kelamin:

Adapun data keseluruhan diperoleh dari pemeriksaan klinis DMF-T oleh dokter gigi dengan dibantu oleh tim peneliti. Objek penelitian, para guru dan staf sekolah kooperatif selama proses pengambilan data berlangsung. Data hasil penelitian gambaran status karies selanjutnya disusun secara sistematis 
dalam bentuk tabel yang memuat identitas, usia, jenis kelain dan hasil pemeriksaan def-t/DMF-T siswa sekolah dasar di kota Malang. Kemudian data tersebut dianalisa dan disajikan dalam bentuk tabel hasil pemeriksaan defT/DMF-T sebagai berikut:

Tabel 2 Hasil Pemeriksaan def-t siswa sekolah dasar di Kota Malang (Oktober 2015)

\begin{tabular}{cccc}
\hline \multirow{2}{*}{ Komponen } & \multicolumn{2}{c}{ Jenis Kelamin } & \multirow{2}{*}{ Jumlah } \\
\cline { 2 - 3 } & Perempuan & Laki-Laki & \\
\hline D & 372 & 440 & 812 \\
E & 305 & 286 & 591 \\
F & 9 & 4 & 13 \\
Total & 686 & 730 & 1416 \\
\hline
\end{tabular}

Dari tabel 2 dapat diketahui bahwa siswa sekolah dasar usia 6-12 tahun di kota Malang menunjukkan gambaran status kesehatan gigi (def-t) yang berbeda antara laki-laki dan perempuan. Pada komponen nilai decay, laki-laki lebih tinggi dibanding perempuan dengan 440 gigi berlubang. Sementara itu, perempuan lebih tinggi pada nilai komponen exfoliasi dibanding pada lakilaki dengan 305 gigi yang hilang atau telah dicabut. Pada nilai komponen filling, siswa sekolah SD perempuan sebanyak 9 dan pada laki-laki 4 . Sementara itu, hasil pemeriksaan DMF-T siswa sekolah dasar di Kota Malang (Oktober 2015).

Tabel 3 Hasil pemeriksaan DMF-T siswa sekolah dasar di Kota Malang (Oktober 2005)

\begin{tabular}{cccc}
\hline \multirow{2}{*}{ Komponen } & \multicolumn{2}{c}{ Jenis Kelamin } & Jumlah \\
\cline { 2 - 3 } & Perempuan & Laki-Laki & \\
\hline D & 107 & 106 & 213 \\
M & 0 & 0 & 0 \\
F & 4 & 1 & 5 \\
Total & 111 & 107 & 218 \\
\hline
\end{tabular}

Dari tabel 3 dapat diketahui bahwa hasil pemeriksaan DMF-T siswa sekolah dasar usia 6-12 tahun di kota Malang menunjukkan kemiripan antara laki-laki dan perempuan, terutama pada nilai Decay. Sementara itu, nilai komponen
Filling pada perempuan dan laki-laki menunjukan angka berturut-turut 4 dan 1 . Adapun nilai decay, missing dan filling secara total dapat diamati pada tabel berikut ini:

Tabel 4 Tabel hasil pemeriksaan def-t dan DMF-T siswa sekolah dasar kota Malang (Oktober 2015)

\begin{tabular}{|c|c|c|c|}
\hline \multirow[t]{2}{*}{ Komponen } & \multicolumn{2}{|c|}{ Indeks } & \multirow[t]{2}{*}{ Jumlah } \\
\hline & def-t & DMF-T & \\
\hline Decay & 812 & 213 & 1025 \\
\hline Exfoliated/Missing & 591 & 0 & 591 \\
\hline Filled & 13 & 5 & 18 \\
\hline Total & 1416 & 218 & 1634 \\
\hline
\end{tabular}

Dari tabel 4 dapat diketahui bahwa komponen decay menunjukkan nilai total 1025. Sementara nilai missing total adalah 591 dan filling adalah 18. Hasil pemeriksaan def-t/DMF-T selanjutnya dianalisa dengan menggunakan rumus indeks def-t/DMF-T menurut WHO. Adapun hasil analisa indeks DMF-T / def-t penelitian ini dapat disajikan pada tabel berikut: 
Tabel 5 Indeks def-t/DMF-T siswa SD berdasarkan jenis kelamin di Kota Malang (Oktober 2015)

\begin{tabular}{|c|c|c|c|}
\hline \multirow[t]{2}{*}{ Jenis Kelamin } & \multicolumn{2}{|c|}{ Indeks } & \multirow[t]{2}{*}{ Total } \\
\hline & def-t & DMF-T & \\
\hline Laki-Laki & 5,03 & 0,74 & 5,77 \\
\hline Perempuan & 4,93 & 0,79 & 5,72 \\
\hline
\end{tabular}

Dari tabel 5 dapat diketahui bahwa indeks def-t/DMF-T secara umum pada laki-laki sedikit lebih tinggi dibanding pada perempuan yaitu 5,77 dibanding
5,72. Adapun indeks def-t dan DMF-t secara total dapat disajikan pada tabel 6 berikut ini:

Tabel 6 Indeks def-t/DMF-T siswa SD di Kota Malang (Oktober 2015)

\begin{tabular}{cc}
\hline Indeks & Nilai \\
\hline def-t & 4,98 \\
DMF-T & 0,77 \\
Total & 5,75 \\
\hline
\end{tabular}

Dari tabel 6 dapat diketahui bahwa indeks def-t pada siswa sekolah dasar baik laki-laki dan perempuan adalah 4 , 98. Sementara itu, untuk indeks DMF-T kedua jenis kelamin adalah 0,77 , sehingga pada indeks def-t/DMF-T total diperoleh angka 5,75.

\section{PEMBAHASAN}

Hasil analisa data yang telah disajikan dalam tabel selanjutnya dikaji dengan teori yang berlaku. Indeks DMF$\mathrm{T}$ (total) pada penelitian ini menunjukan nilai 5,75. Klasifikasi indeks DMF-T dalam penelitian ini menurut WHO (2003) adalah tinggi sebab dalam rentang 4,5 - 6,5. Indeks DMF-T tinggi mengindikasikan bahwa prevalensi karies gigi siswa sekolah dasar usia 6-12 tahun di Kota Malang yang pemeriksaannya dilakukan pada bulan Oktober 2015 adalah tinggi.

Karies gigi merupakan penyakit kronis dengan prevalensi yang cukup tinggi pada anak usia sekolah dasar (6-11 tahun) (CDC, 2014). Sementara itu, menurut WHO (2000), target pelayanan kesehatan gigi 2010 antara lain anak umur 5 tahun $90 \%$ bebas karies dan anak umur 12 tahun mempunyai tingkatkeparahan kerusakan gigi (Indeks DMF-T) sebesar 1. Terkait dengan target tersebut, maka temuan dalam penelitian ini dianggap belum sesuai dengan harapan WHO.
Salah satu faktor resiko karies adalah tingkat kebersihan mulut yang buruk (WHO, 2012). Buruknya kebersihan mulut salah satunya disebabkan karena perilaku menjaga kebersihan mulutnya kurang. Anak usia antara 6-12 tahun atau anak usia sekolah masih kurang mengetahui dan memelihara kebersihan gigi dan mulut (Depkes, 1999). Selain itu, anak-anak umumnya senang makan makanan yang manis dan jarang membersihkannya, sehingga gigi geliginya banyak yang mengalami karies (Zein, 2005 dalam Listriana, 2011). Dalam penelitian ini, dapat diperkirakan juga bahwa salah satu faktor resiko tingginya angka DMF-T anak sekolah dasar di Kota Malang (Oktober 2015) adalah kebersihan mulut yang kurang akibat perilaku menjaga kebersihan mulut yang tidak sesuai.

Seringnya mengkonsumsi makanan manis oleh anak-anak memang tidak

terelakkan. Sementara, makanan mengandung gula sebagai salah satu faktor yang menyebabkan karies gigi. Hal ini didukung dengan penelitian oleh Rosidi, dkk (2013) yang menyatakan bahwa terdapat hubungan yang signifikan antara kejadian karies gigi dengan konsumsi makanan yang kariogenik. Seperti diketahui bahwa, glukosa yang terkandung dalam makanan manis merupakan faktor utama terjadinya karies gigi selain S.mutans pada permukaan 
enamel gigi (Hakan et al., 2013). Lamanya waktu paparan glukosa pada permukaan gigi adalah prinsip dasar terbentuknya karies gigi. Asam yang diproduksi oleh bakter sebagai hasil fermentasi glukosa tersebut akan bertahan selama 20-40 menit pada permukaan gigi (Hakan et al., 2013).

Variabel jenis kelamin pada penelitian ini juga menunjukkan perbedaan hasil indeks DMF-T. Adapun hasil dari penelitian ini, indeks DMF-T pada laki-laki lebih tinggi dibandingkan pada perempuan. Hal ini diprediksi terkait dengan factor minat untuk memeriksakan gigi ke dokter gigi. Menurut Burt dan Eklund (2006), perempuan cenderung mengunjungi dokter gigi untuk perawatan kesehatan giginya dibandingkan laki-laki.

Perbedaan hasil indeks DMF-T laki-laki

dan perempuan pada penelitian ini, secara umum berbeda dengan hasil penelitian yang lain. Menurut Luckas dan Largaespadda (2006), prevalensi karies gigi pada perempuan lebih tinggi dibandingkan pada laki-laki. Hal ini disebabkan karena erupsi gigi pada perempuan lebih awal dibandingkan pada laki-laki sehingga paparan gigi terhadap substansi kariogenik dianggap lebih lama (Luckas dan Largaespadda, 2006). Selain itu, perempuan lebih mudah untuk mendapatkan akses terhadap persediaan makanan termasuk juga lebih seringnya perempuan dalam mencicipi makanan selama proses penyiapan makanan seharihari (Luckas dan Largaespadda, 2006). Untuk wanita dewasa, kehamilan juga merupakan faktor resiko yang meningkatkan prevalensi kerusakan gigi termasuk karies gigi (Luckas dan Largaespadda, 2006).

Tingginya nilai decay (1025) dan rendahnya nilai filling (18) pada penelitian ini juga menjadi perhatian. Hal ini didukung oleh penelitian yang dilakukan oleh Darwita dan Wisnu (2000) bahwa peningkatan skor DMF-T pada murid-murid sekolah dasar pada umumnya yang terbesar adalah komponen decay dibandingkan dengan skor missing dan filling. Peningkatan skor decay cenderung seiring dengan peningkatan usia murid (Darwita dan

Wisnu, 2000). Faktor ekonomi (penghasilan) menjadi salah satu asumsi tingginya nilai decay pada anak usia sekolah (Darwita dan Wisnu, 2000). Hal ini dapat diasumsikan bahwa anak sekolah tidak memeriksakan gigi yang karies untuk dilakukan perawatan pada sarana kesehatan yang layak (Darwita dan Wisnu, 2000). Menurut CDC (2000) faktor status sosial ekonomi mempengaruhi prevalensi karies gigi.Dalam penelitian ini tidak melihat hubungan antara faktor social ekonomi dengan prevalensi karies gigi pada anak sekolah dasar. Sehingga, perlu adanya penelitian lebih lanjut.

Sementara itu, komponen missing atau exfoliated pada penelitian ini menunjukan nilai 591. Hal ini dapat diasumsikan pada masa sekolah dasar (usia 6-12 tahun) terjadi masa pergantian gigi susu ke gigi permanen sehingga terdapat beberapa gigi yang hilang pada saat dilakukan pemeriksaan (American Academy of Pediatric, AAP, 2010). Siswa sekolah dasar juga sering kali tidak bisa menjelaskan penyebab gigi yang hilang apakah dikarenakan karies gigi atau hilang secara alami (Hiremath, 2011). Oleh karena itu, nilai missing atau exfoliated dalam penelitian ini dianggap cukup banyak.

\section{KESIMPULAN}

Dalam penelitian ini, telah diperoleh beberapa kesimpulan terkait prevalensi karies gigi pada anak usia sekolah dasar yang berada di sekolah dasar kota Malang (SDN Kauman 2 dan SDN Percobaan 2 Malang). Pengukuran prevalensi karies gigi menggunakan indeks DMF-T pada anak usia 5-12 tahun baik laki-laki dan perempuan. Adapun nilai indeks DMF-T pada penelitian menunjukan nilai 5, 75 yang bermakna prevalensi karies gigi anak sekolah dasar Kauman 2 dan Percobaan 2 Malang adalah tinggi (WHO,2003).

Sementara itu, indeks DMF-T pada anak sekolah dasar laki-laki menunjukkan lebih tinggi dibandingkan pada anak 
perempuan yaitu 5,77 dibandingkan 5,72. Dalam penelitian ini, tidak dikaji faktor resiko yang mempengaruhi perbedaan indeks DMF-T pada laki-laki dan perempuan. Namun, asumsi determinan yang mempengaruhi yaitu anak laki-laki cenderung enggan untuk memeriksakan gigi ke fasilitas kesehatan dibandingkan dengan anak perempuan (Luckas dan Largaespadda, 2006).

Dalam penelitian ini juga diperoleh temuan nilai decay pada indeks DMF-T yang cukup tinggi baik pada laki-laki atau perempuan sementara nilai filling dianggap rendah.Hal ini menjadi pengamatan, sebab terdapat asumsi bahwa anak-anak sekolah dasar tersebut tidak memeriksakan kondisi karies gigi yang dialaminya ke dokter gigi atau fasilitas kesehatan lainnya. Sementara nilai missing atau exfoliated, diasumsikan cukup banyak dikarenakan pada usia sekolah dasar terjadi pergantian gigi geligi. Selain itu, anak usia sekolah dasar kurang bisa menjelaskan riwayat terjadinya kehilangan gigi geliginya.

Beberapa kekurangan pada penelitian ini antara lain sample penelitian belum dapat digeneralisasikan pada semua anak sekolah dasar di Kota Malang. Selain itu, variable jenis kelamin dan usia juga masih sangat terbatas untuk menggambarkan status karies gigi anak usia sekolah.

\section{SARAN}

Dari kesimpulan diatas dapat diajukan beberapa saran sebagai berikut:

1. Perlu adanya kebijakan terkait kemudahan akses untuk mendapatkan perawatan kesehatan gigi dan mulut bagi anak usia sekolah dasar. Dalam hal ini, tenaga kesehatan juga perlu untuk turut berpartisipasi aktif dalam memberikan pendidikan kesehatan gigi dan mulut serta perlunya kunjungan rutin ke fasilitas kesehatan gigi dan mulut yang ada.

2. Perlu adanya program peningkatan kesehatan gigi dan mulut di sekolah yang komprehensiv yang termuat dalam UKGS. Sehingga harapannya, tidak bergantung sepenuhnya ke tenaga kesehatan yang berkunjung ke sekolah.

3. Perlu adanya penelitan lanjutan mengenai gambaran status karies gigi anak sekolah dasar di Kota Malang terutama dikaitkan dengan beberapa faktor resiko. Sehingga diharapkan dapat menunjukan situasi dan kondisi yang lebih nyata dan selanjutnya memperoleh solusi yang terbaik untuk mengurangi prevalensi karies gigi anak sekolah dasar di Kota Malang.

\section{DAFTAR RUJUKAN}

American Academy of Pediatric (AAP). 2010. A Pediatric guide to childrens's oral health flip chart. (online), https://www2.aap.org/oralhealth/doc s/OralHealthFCpagesF2_2_1.pdf. Diakses tanggal: 24 Nopember 2015

Bagramian, R., Godoy, F., Volpe, A. 2009 ' The global increase in dental caries. A pending public health crisis', (Online), http://amjdent.com/Archive/2009/Ba gramian $\% 20$ \%20February\%202009.pdf. Diakses tanggal: 30 Maret 2015.

BPS. 2012. Data Statistik Indonesia, (online), http://www.datastatistikindonesia.com/portal/index.php?opti on $=$ com_content $\&$ task $=$ view $\& i d=93$ $3 \&$ Itemid $=965$. Diakses tanggal 9 februari 2013.

Burt, B.A dan Eklund. 2005. Dentistry, Dental Practice and The Community $6^{\text {th }}$ ed. Philadelphia, Sauders Company. P 194-195, 239-243

Centers of Control Diseases Prevention (CDC). 2000. Recommendation for using fluoride to prevent and control dental caries in the United States, (Online), http://www.cdc.gov/mmwr/preview/ mmwrhtml/rr5014a1.htm. Diakses tanggal: 18 Nopember 2015.

Centers of Control Diseases Prevention (CDC). 2013. Preventing dental caries with community programs, (online), 
http://www.cdc.gov/oralhealth/publi cations/factsheets/dental_caries.htm. Diakses tanggal 30 Maret 2015.

Centers of Control Diseases Prevention (CDC). 2014. Hygiene Related Disease: Dental dcaries (tooth Decay), (Online), http://www.cdc.gov/healthywater/hy giene/disease/dental caries.html. Diakses tanggal: 16 Nopember 2015

Darwita, Risqi, R. dan Wisnu, Johanes. 2000. Kecenderungan karies gigi pada anak sekolah dasar di Serpong dan Jakarta Barat, (Online), http://download.portalgaruda.org/art icle.php? article $=341253 \&$ val $=6661$ \&title=KECENDERUNGAN\%20P REVALENSI\%20KARIES\%20GIG I\%20PADA\%20ANAK\%20SEKOL AH\%20DASAR\%20DI\%20SERPO NG\%20DAN\%20JAKARTA\%20B

ARAT. Diakses tanggal: 17 Nopember 2015.

Departemen Kesehatan R.I. Direktorat Jendral Pelayanan Medik, Direktorat Kesehatan Gigi. 1999. Profil Kesehatan Gigi Dan Mulut Di Indonesia Pada Pelita VI. Jakarta: Depkes RI. halaman 17 - 69.

Departemen Kesehatan Republik Indonesia. 2008. Riset Kesehatan Dasar 2007, (Online), https://www.k4health.org/sites/defau lt/files/laporanNasional\%20Riskesd as\%202007.pdf. diakses tanggal 31 Maret 2015.

Dewanti. 2012. Hubungan tingkat pengethauan tentang kesehatan gigi dengan perilaku perawatan gigi pada anak usia sekolah di SDN Pondok Cina 4 Depok, [Online], http://lib.ui.ac.id/file?file=digital/20 311320-S42783-

Hubungan\%20tingkat.pdf. Diakses tanggal 30 Maret 2015.

Hakan, Colak; Coruh T.D; Mehmet, D. dan Mehmet,M. 2013. Early childhood caries update: A review of causes, diagnoses and treatmens, (Online)

http://www.ncbi.nlm.nih.gov/pmc/ar ticles/PMC3633299/. Diakses tanggal: $\quad 18 \quad$ Nopember
2015.Hiremath, SS. 2011. Textbook of preventive and Community Dentistry. $\quad 2^{\text {nd }} \quad e d, \quad$ (online), https://books.google.co.id/books?id= Tz9cWJ3yUycC\&pg=PA194\&lpg= PA194\&dq=missing+or+exfoliation + knowledge + children \&source $=$ bl\&o ts=PyfHQtiuQW\&sig=O1R4saSFY w2bk3cu-

oHYLWvSyQo\&hl=en\&sa=X\&ved $=0$ ahUKEwiS1pGNnoXKAhWLA4 4KHdSvCoIQ6AEIMTAE\#v=onepa ge\& $\mathrm{q}=$ missing $\% 20$ or $\% 20$ exfoliation $\% 20 \mathrm{knowledge} \% 20$ children $\& \mathrm{f}=$ fals e. Diakses tanggal: 24 Nopember 2015

Listrianah., dan Malaka, Tan. 2011. Faktor-Faktor Yang Berhubungan Dengan Risiko Kejadian Karies Dentis Pada Murid SMP Di Kota Palembang,

(Online), http://lppmbinahusada.net/e disi- 13. Diakses tanggal: 16

Nopember 2015.

Lukacs, J.R. dan Largaespada, L.L. 2006. Explaining sex differences in dental caries prevalence: saliva, hormones, and life-history etiologie, (Online) http://www.ncbi.nlm.nih.gov/pubme d/16788889. Diakses tanggal: 18 Nopember 2015.

Machfoedz dan Zein. 2005. Menjaga Kesehatan Gigi dan Mulut Anakanak Ibu Hamil. Yogyakarta ; Fitramaya

Riyanti E. 2005. Pengenalan dan perawatan kesehatan gigi anak sejak dini. [serial online], http://resources. unpad.ac.id/unpadcontent/uploads/ publikasidosen. Pdf. Diakses tanggal 30 Maret 2015.

Rosidi, Agus; Haryani, Siti dan Adimayanti, Eka. 2013. Hubungan Antara Konsumsi Makanan Kariogenik Dengan Kejadian Karies Gigi Pada Anak SDN 1 Gogodalem Kec. Bringin Kab. Semaran,(Online), http://download.portalgaruda.org/art icle.php?article $=179289 \& \mathrm{val}=426 \&$ title=HUBUNGAN\%20ANTARA\% 
20KONSUMSI\%20MAKANAN\%2

OKARLOGENIK\%20\%20DENGA

N\%20KEJADIAN\%20KARIES\%20

GIGI\%20\%20\%20PADA \%20ANA

K\%20SDN\%201\%20GOGODALE

M\%20KEC.\%20BRINGIN\%20KA

B.\%20SEMARANG. Diakses

tanggal: 18 Nopember 2015

Sondang P dan Hamada T. 2008. Menuju gigi dan mulut sehat. Medan: USU Press. h.4-15,4-24

World Health Organization (WHO). 2000. Oral health information

systems, (Online)

http://www.who.int/oral_health/a ction/information/surveillance/en I. Diakses tanggal: 16 nopember 2015.

World Health Organization, (WHO). 2012.OralHealth,(Online) http://www.who.int/mediacentre/fact sheets/fs318/en/. Diakses tanggal: $26 \quad$ Nopember 2015. 
